\title{
Capitalism, A Double-Edged Sword
}

\author{
Muhammad Busyairi \\ \{muhammadbusyairi@yahoo.com\} \\ Regency Government of West Lombok, Jl. Soekarno - Hatta, Dasan Geres, Gerung, Kabupaten \\ Lombok Barat, Nusa Tenggara Barat. 83363
}

\begin{abstract}
Many researchers argue that Capitalism represents the interest of the rich and the superrich which then makes the poor suffer. However, analysing Urry's [6] article "Consuming the Planet To Excess", indicates that Capitalism has a negative effect on the rich as well. Using literature study and Urry's article as the main source, this article finds double edges of Capitalism. First edge, the proponents of neoliberalism believe that neoliberalism will help the poor, however, it actually makes the poor suffer. Second, the opponents argue that neoliberalism benefits the rich, however, it also can disadvantage the rich. This applies in the case of places of consumption to excess which warm the world. At these places, the rich feel free, not feel guilty, and they seem to be happy. In fact, they are experiencing a kind of addiction. This article will also provide a unit of solution offered by McIntyre-Mills which is called "The Planetory Passport" to prevent the worse global warming.
\end{abstract}

Keywords: Capitalism, Global warming, Addiction, Planetory passport

\section{Introduction}

Neoliberalism as the result of the "Washington Consensus," is a market-based economy pioneered by the United States of America and the international financial institutions. This edology minimizes the roles of governments [1]. According to Gary personal interests is they point of neoliberalism [1]. Neoliberalism has some interchangable names such as free trade, capitalism, and globalisation [2,3]. Even, some authors name it market-based governance [4]. One famous term of neoliberalism is 'accumulation by dispossession' coined by Harvey [5], which means the rich occupy the wealth and power of public by dipossession. Some believe that this 'business as usual' ideology as the major ideology shaping our world. Even they justify today as the era of neoliberalism [1], which is according to Urry, 'the only game in town' [7].

Opponents of capitalism criticize the ideology as the interests of the rich, the superrich [2] and the corporatists [7], while the poor is the victims. Chang and Grabe assumed capitalism has created big gaps between the rich and the poor through poverty, inequality, and unevennes in social and economic [2,8]. However, through "Consuming the Planet to Excess", Urry [6] indicates that both the rich and the poor may suffer from the negative impacts of capitalism. By referring to Urry's article [6], this paper will critically analyze how capitalism brings mess for the rich and the poor in the context of climate change. This paper argues that capitalism is like a a double-edged sword. It not only creates poverty and inequality to the poor, but it also causes addiction for the rich which encourages global warming threats for both the rich and the poor. 


\section{Research Method}

This study uses secondary data collected from books, e-books and related journal articles with the main article is Urry's "Consuming the Planet To Excess" [6]. The use of secondary data was chosen due to its availability and accessibility. This research used qualitative methodology, that is, a literature study. It is an exploration of the way certain concepts are applied in practice [20], in this research context, referring to the concept of Capitalism, Climate Change, and McIntyre-Mills's Planetory Passport.

\section{Result And Discussion}

The capitalism's hardliners claim that their ideology offers solutions to reach global welfare. A proponent, Mike Moore, for example, claims that opening market as the main feature of capitalism is the most trusted strategy to give assistance for the poor [9]. They claimed that poverty rate has decreased significantly during the past two decades [8]. Moreover, a study by World Bank in 2004 showed a drastic decline of poverty rate during the period of 1990-1998 with a 6 percent difference [10]. However, the study was found to have much margin of error [10]. Chang and Grable are among those who were pessimistics with the decline of poverty rate as the result of capitalism. They argued that the decline was caused by two biggest population countries, China and India, where both were not applying Capitalism ideology [8]. Therefore, the claim capitalism has managed to reduce the level of poverty is doubting.

Liberalists claim that Capitalism will trigger equality, not poverty and inequality. Furthemore, they believe the haves and the haves not will get an equal proportion in the economic growth [8]. However, in reality, rather than broadening growth, Capitalism has caused great inequality in the world. For instance, during the 20th century, the gap between the rich and the poor increased by twenty percent [8]. Capitalism has encouraged the rich moved to be the superrich and the workers into the poor [7]. In December 2006, a study conducted by the United Nations found that more than half of the global wealth was occupied by only two percent of the world's population, and they were categorized the wealthiest [6]. Hay specifically found there was a dramatic income gap in the United States of America, in which, the wealthiest $1 \%$ who had only $9 \%$ of national income in 1970 increased to $40 \%$ in 2011 [11]. It shows the big gap between the wealthy and the needy due to the ideology of Capitalism that shapes our world today.

As explained above, the first edge of the capitalism sword is used to create poverty and inequality. However, it has another edge which other than 'slashes' the poor, it might become a 'backfire' for the wealthy they have never predicted.

Urry's article, "Consuming the Planet to Excess" [6] explicitly shows contradictions of capitalism. "Consuming the Planet to Excess" which indicates the implementation of neoliberal policy encourages global warming. Tens of year ago Karl Polanyi has reminded us about the danger of relying on market mechanism. According to him, putting capitalism as the only determinant for our fate and environment could cause destructions of our neighbourhoods, even we might not be able to generate raw materials and finally no food will be available [6]. Today, as predicted by Polanyi, the world is threatened by global warming, in Urry's world, 'the 20th century has left a bleak legacy for human beings in the 21 st century [6]. Capitalism shaping our world today has negatively affected the environment. Overconsumption that creates climate changes and removes a few elements of life and its predictable improvement is the the result of 
uncontrolled incredible power generated by capitalism. Urry names capitalism as a genie: "It was the genie that was let out of the bottle and cannot "easily' be put back into the 'bottle"" [6].

Reading "Consuming the Planet to Excess" relatively gives us an understanding that capitalism has caused natural threats for human beings. It cannot be denied that climate changes exist. Also, human activities have drastically upgraded the amount of carbon emissions and created global warming. The proponents of capitalism ideology should realize that climate change real. Thousands of scientists through their much research have recognized and found the existence of climate change, it is not just a story or a myth but a fact.

However, realizing the risks of capitalism policy related to its roles in changing the climate, why "Consuming the Planet to Excess" keeps going and capitalism has not much efforts to cope with it? Two points should be the answers of the question. First, as many researchers have argued, capitalism represents the interest of the wealthy and large multinational corporations $[2,12]$. Richard Rothschild, for example, argues that policies to combat global warming were 'an attack on middle class American capitalists' [12]. Naomy Klein clearly states that 'carbon is not the real problem, but rather a symptom of the real problem, global capitalism' [12]. Thus, it can be assumed that capitalism has not a good will to minimize gas emissions [13], for one main possible reason, to keep benefiting large corporations.

Second, in contrast to the fact that climate change is real, most of their adverse effects as mentioned in Urry's article are still predictions that have not happened yet. Some facts, for example, global temperature has increased at least $0.74{ }^{\circ} \mathrm{C}$ due to greenhouse gases. Also, in 2000, the World Health Organisation estimated about 150,000 deaths a year with concentration in the Thirld World are the results of changes in climate [6].

However, other than those facts, Urry [6] provides more information containing possibilities or something that may or will happen. First, the effects of climate change may endanger fifty million people. Second, the super power country, America declared that the existence of climate changes will stimulate wars among nations and natural disasters as well. Even, this Uncle Sam country believes that the threats of climate change towards global stability are much bigger than those of terrorism. Third, by the end of this century, gas emissions could threaten human-beings living on earth. And fourth, it is predicted that the rising sea levels will cause floods of some vital infrastructures such as roads, railways, and airport airways which positively will affect food and other sources supplies [6].

In addition, the thesis statement of Urry's article uses 'future or present perfect tense' rather than past tense. It shows that the threats of capitalism towards human beings have not occured but are predictions. Therefore, it might be the reason, capitalists keep applying policies through 'Consuming the Planet to Excess' because they get a lot of benefits while global warming as the results of climate change has not dramatically 'attacked' them. While the poor is still the main victims, that is, not only the number of deaths which concentrates in the poor South but also climate changes will reduce living standard and life capabilities the poor in the South. Thus, the use of this article is to remind us the possible negative effects of climate change and how to cope with it. This will be beneficial especially for those who do not take a part in consuming the planet to excess [6].

To cope with the effects of climate change, McIntyre-Mills [11,14,15] suggests a solution in a term named 'Planetary Passport'. The aim of this concept is to inspire loyalty to the planet and as a monitoring system to protect living system. The way to implement it is by balancing between 'environmental sustainability, consumption choices and well-being' [11].

In her 'Planetary Passport' approach, McIntyre-Mills raises some interconnected notes and actions. First, we are a part of web of life that need to maintain good relationship among individuals and among individuals with animals, voiceless, and the environment. Second, global 
consciousness that 'we do not live in separate containers; we live in interconnected and overlapping regions where our fates are interlinked' [11]. Therefore, we have no choice, there no Planet B or the Earth B, we are unable to exit the planet. Balancing between ideal capabilities approach and measuring consequences of capitalism are the way to protect our planet for today and future generation [11]. Since the problems are global, addressing the differences through 'loyalty' and 'voice' suggested by Albert Hirschman [14] is one solution. Third, McIntyre-Mills cites Dobson who suggests to care to the environment by implementing two forms of citizenship. The first form is ecological citizenship which refers to regulations and control, and the environment citizenship in regards to the personal choices of citizens for the common good because they relate to the ecological footprints [11]. According to McIntyre-Mills, we need to create ecological citizenship through education programs and cooperated with natural resource organisations. Also, the increased size of the ecological footprint of cities and the gap between the poor and the rich is not a static condition [11]. They are changeable to better ones. Fourth, since we are depending on the environment, following the Global Neighbourhood program which contains justice, equality, respect, care, integrity and global ethics should be a means to respect others including the voiceless and the environment [11]. Fifth, we have to recognize, as described by Rose, that 'we are the land'. The land grew the people, and then the people grew their country [11]. We are interconnected, interdepencende, and inseparated. When a human considers himself the most right to live on this planet, he may disregard other species' rights [11].

"Consuming the Planet to Excess" provides some examples of specific places. They involve a number of interdependent components that remake consumption, pleasure, work, friendship and family life. Some places mentioned in the article are Dubay, Zaha Hadid on the island, Dellis Cay in the Caribbean, and Atlantic City. Urry [6] questions the development of those places that have to be travelled to. Capitalists provided these places to support the increased freedom of the people, said Giddens [6]. The consumption to excess of these leisure places comes from freedom. When the rich or the superrich enjoy the excessive freedom with no rule or feeling guilt [16], it will lead to addiction. This addiction will cause physical or emotional dependence on the products and services provided. McIntyre-Mills [11] describes only a few people realize consumption choices and their motivation to consume excessively. However, according to Pretty, it has been argued that having reached a certain point, increased consumption does not bring to more happiness [11]. An increase in economic growth and consumption are not in line with feeling happier. In fact, it may present 'existential risks' [11]. A quote for the Apocalypto film could draw this condition. A man was never satisfied with what given by the Earth, he kept asking. One day the world said: I am no more and I have nothing left to give. If human beings consume to excess what provided by the Earth, again and again, our planet may, not only have nothing to give but also cause great disasters.

Those people are having an addiction to what provided by the capitalists. As commonly defined, addiction is an out of control action of an addicted person. So, when all get corced into being 'free to choose' [6], they will lead to addicted people, said Giddens [6]. A condition of addiction to specific leasure places of consuming to excess is like addicted to illegal drugs. The wealthy can buy, enjoy and finally get addicted. They may physically or emotionally seem to be happy in which at the same time they are relying on those drugs to consume, again and again. Here, having an addiction is seen happiness. Davis and Monk name those places of excessive consumption as 'evil paradises' [6], places to have 'false happiness' which may cause adverse effects on consumers and the environment.

Furthermore, such freedom breaks the substance of the government ethical axiom 'we can be free and diverse to the extent that we do not undermine the freedom and diversity of others- 
or the next generation of life' [15]. Yes it is true that we have freedom, but it should not undermine the biosphere we depend [15]. Consuming to excess in those places by wasting a lot of energy that warms the planet is far from the freedom that ought to be. That kind of freedom absolutely violates others' freedom. The sophisticated development of those superrichspecialized areas that leads to addiction and threats is in line with what McIntyre-Mills says "that some of the results of our attempts at development are the monsters of our own creation" [11].

In addition, those places show an ironic condition. While they are considered to have 'potentially significant addiction', this world is inhabited over two billion people who live less or similar to two dollars a day. Those places of consumption excess have great social exclusion, security and glorious buildings. All these facilities are not compatible with our environment and ethics as human beings [6]. Homer-Dixon elaborated another ironic order, that today more than one billion of the world population are categorized obese. This number is equal to the number of underfed and undernourished people [6]. Both ironic states draw the sharp inequality between the rich and the poor which is the main shortcoming of capitalism [2]. As a result, except indicating addiction and wide inequality, those places 'contribute' to the increased level of global warming. With their great buildings, wasteful use of energy and water, and much amount of oil use for people transport in and out [6], they generate hyper-high-carbon emissions. According to Greenfield, 'the addiction of the powerful to consume luxury goods is at the expense of the life of the future generations [14].

Therefore, it is very important to encourage a more balanced state between the rich and the poor to help the poor enjoy a better life and equality. Also, our relationship to the nature with an environmentally friendly relation should be created. One key point noticed by Wilkinson and Pickett that to link between well-being and attempts to reduce the effects of global warming should involve 'limiting consumerism' [11]. It is expected, limiting consumerism should lead to both minimizing 'waste' that warms the planet and helping the needy. We have to always remember that we live on the same planet requiring us to "appreciate our dependency on other species in a shared and separate protected habitats" [11].

Increased social and economic equality is likely to be the key words to lessen consuming to excess at the expense of the majority. This effort should be done for the sake of current and future generations. Thus, all we need is a balance between individual and community to arrive to sustainable lives protecting the rights of human beings, voiceless, and our environment [11].

\section{Conclusion}

This paper concludes that although climate change is real, most of its possible impacts are still predictions. It might be the reason capitalists set too low to the consequences that may happen. As an ideology 'shaping our world today', capitalism has shaped the world following the interest of the rich and the corporatists. The claim that poverty has decreased is doubting with the fact of the big gap between the rich and the poor, which is the first edge of capitalism sword. Moreover, the poor of the South suffered and is estimated to suffer more than that of the rich North.

"Consuming the Planet to Excess" askes us to think that whether the threats of climate changes are real or not, we as human beings should be vigilant with those potential threats. Specific places built by capitalists could lead to 'false happiness' or addiction which finally results in global warming. This is the second edge of capitalism which disadvantage both the 
rich and the poor. McIntyre-Mills offers a softer but effective solution involving consciousness and real programs. According to her, an easy action such as "opportunities for families to connect with the earth and water through play and adventure" [11] could be initial strategies to avoid the impacts of climate changes in the future.

Acknowledgments. This article was a paper which was submitted to pursue my master degree at Master of Public Administration (Policy), Flinders University, Australia

\section{References}

[1] Thorsen. D.E. and A. Lie.: What Is Neoliberalism University of Oslo (2006)

[2] Chomsky.: Profit over people (Neoliberalism and global order: Seven Stories Press) (1999)

[3] Serrano, M. R. and E. Xhafa.: The Quest for Alternatives beyond (Neoliberal) Capitalism, Global Labour University Working Paper (2011)

[4] Warner M.E..: Market-based governance and the challenge for rural governments: US trends. Social Policy \& Administration, Vo. 40.pp. 612-631 (2006)

[5] Harvey, D. A.: brief history of neoliberalism. (USA: Oxford University Press) (2007)

[6] J. Urry.: Consuming the planet to excess. Theory, Culture \& Society. Vol. 27.pp. 191-212 (2010)

[7] N. Klein.: The shock doctrine The rise of disaster capitalism Macmillan (2007)

[8] A. Greig, D. Hulme, and M. Turner.: Challenging global inequality: development theory and practice in the 21st century, Palgrave Macmillan (2017)

[9] A. Shaikh.: The economic mythology of neoliberalism. Neoliberalism: A critical reader.pp. 41-49 (2005)

[10] R.H. Wade.: Is globalization reducing poverty and inequality. World development. Vol. 32.pp.567589 (2004)

[11] J. McIntyre-Mills.: Planetary Passport Re-presentation, Accountability and Re-generation.Springer (2017)

[12] N. Klein.: Capitalism vs. the Climate-Denialists are dead wrong about the science. But they understand something the left still doesn't get about the revolutionary meaning of climate change. The Nation (2011)

[13] J. Hovi, D.F. Sprinz and G. Bang.: Why the United States did not become a party to the Kyoto Protocol: German, Norwegian, and US perspectives. European Journal of International Relations.Vol. 18.pp. 129-150 (2012)

[14] J. McIntyre-Mills, R. Wirawan, B.S. Laksmono, I. Widianingsih and N.H, Sari.: Pathways to Wellbeing-Low Carbon Challenge to Live Virtuously and Well: Participatory Design and Education on Mitigation, Adaptation, Governance and Accountability. In Balancing Individualism and Collectivism.pp. 37-73 (2018)

[15] J.McIntyre-Mills and D. Vries.: Part 2 Transformation from Wall Street to Well-being Systems Research and Behavioral Science.Vol. 30.pp.444-469 (2013) 